\title{
Anagliptin in the treatment of type 2 diabetes: safety, efficacy, and patient acceptability
}

This article was published in the following Dove Press journal:

Diabetes, Metabolic Syndrome and Obesity: Targets and Therapy

18 March 2015

Number of times this article has been viewed

\author{
Shinya Nishio \\ Mariko Abe \\ Hiroyuki Ito \\ Department of Diabetes, Metabolism \\ and Kidney Disease, Edogawa \\ Hospital Higashikoiwa, Edogawa-ku, \\ Tokyo, Japan
}

Correspondence: Hiroyuki Ito

Department of Diabetes, Metabolism and Kidney Disease, Edogawa Hospital,

2-24-18, Higashikoiwa, Edogawa-ku,

Tokyo, 133-0052, Japan

Tel $+8 \mid 33673$ I22।

Fax +8I 336731229

Email ito@edogawa.or.jp
Abstract: Anagliptin is a novel dipeptidyl peptidase-4 inhibitor that has been available in Japan since 2012. Because anagliptin is not generally used in countries other than Japan, there are only a small number of reports investigating the effects of anagliptin. In the present article, we review the safety and efficacy of anagliptin according to data obtained from preclinical trials and postmarketing studies. The usual dose of anagliptin is $200 \mathrm{mg}$ daily, and increases in the dose up to $400 \mathrm{mg}$ daily have been approved in cases in which the blood glucose-lowering effect is insufficient. In a Phase II trial, the reduction in the $\mathrm{HbA}_{\mathrm{lc}}$ values from baseline after 12 weeks monotherapy with $200 \mathrm{mg}$ and $400 \mathrm{mg}$ of daily anagliptin was $0.75 \% \pm 0.50 \%$ and $0.82 \% \pm 0.46 \%$, respectively, and more than $40 \%$ of the subjects receiving anagliptin at a dose of $200 \mathrm{mg}$ or $400 \mathrm{mg}$ daily achieved an $\mathrm{HbA}_{1 \mathrm{c}}$ level below $6.9 \%$. Furthermore, the levels of $\mathrm{HbA}_{1 \mathrm{c}}$, fasting blood glucose, and postprandial blood glucose were significantly decreased at 52 weeks compared with the baseline values in a Phase III trial investigating the effects of anagliptin included in combination therapy with other oral antidiabetic agents. In a pooled analysis of Phase II and Phase II/III trials, the goal achievement rates for an $\mathrm{HbA}_{1 \mathrm{c}}$ level below $7.0 \%$ at 12 weeks were $40.3 \%, 39.4 \%, 30.0 \%$, and $34.8 \%$ in the patients treated with anagliptin combined with $\alpha$-glucosidase inhibitors, thiazolidinediones, sulfonylureas, and biguanides, respectively. Meanwhile, the serum lipid concentrations significantly improved after the administration of anagliptin in a pooled analysis of Phase III trials, and no serious adverse effects have been reported in preclinical trials. Therefore, the use of anagliptin in patients with type 2 diabetes is considered to be safe and effective for both monotherapy and combination therapy.

Keywords: dipeptidyl peptidase-4 inhibitor, type 2 diabetes mellitus, monotherapy, combination therapy, adverse effect

\section{Introduction}

Treatment with dipeptidyl peptidase-4 (DPP-4) inhibitors, novel oral antidiabetic agents (OADs), results in improvements in the blood glucose levels in patients with type 2 diabetes mellitus following the stimulation of endogenous insulin secretion, inhibition of glucagon release, and reduction of gastric emptying via the enhanced production of incretin hormones (glucagon-like peptide-1 [GLP-1] and gastric inhibitory polypeptide). Sitagliptin, the first DPP-4 inhibitor, was approved for use by the US Food and Drug Administration in 2006 and has been available in Japan since 2009. Seven drugs belonging to this class are currently available for prescription in the clinical setting under the medical insurance law at the time of December 2014 in Japan (Table 1).

Recent trends in the rates of antidiabetic agent prescriptions in our facility are shown in Figure 1. While the number of patients prescribed $\alpha$-glucosidase inhibitors, sulfonylureas, thiazolidinediones, and glinides has been on the decline, 
Table I Pharmacological characteristics and use in the clinical setting in Japan and efficacy of DPP-4 inhibitors in patients with type 2 diabetes based on the data for Phase III clinical trials

\begin{tabular}{|c|c|c|c|c|c|c|c|}
\hline & Sitagliptin & Vildagliptin & Alogliptin & Linagliptin & Teneligliptin & Saxagliptin & Anagliptin \\
\hline $\mathrm{IC}_{50}(\mathrm{nmol} / \mathrm{L})$ & 17.9 & 9.7 & 10 & $\mathrm{I}-3.6$ & 0.9 & 1.3 & 3.3 \\
\hline$T_{\max }(\mathrm{h})$ & $2-5$ & $1.3-2.8$ & $1.0-1.4$ & 6 & $1.0-1.8$ & 0.8 & $0.9-1.8$ \\
\hline$T_{1 / 2}(\mathrm{~h})$ & $9.6-12.3$ & $1.5-5.3$ & $|4.3-2| .8$ & $97-105$ & 2,124 & $6.0-6.8$ & $5.8-6.2$ \\
\hline Inhibition of plasma DPP-4 activity (\%) & $\geq 80$ & $\geq 80$ & $\geq 80$ & $\geq 80$ & $\geq 70$ & $\geq 80$ & $\geq 80$ \\
\hline Increase in active GLP-I levels & $\geq 2$-fold & I.8-fold & 2 -fold & Increase & $\geq 2$-fold & $\geq 2$-fold & $\geq 2$-fold \\
\hline \multicolumn{8}{|l|}{ Dosing } \\
\hline Frequency & QD & BID & QD & QD & QD & QD & BID \\
\hline \multicolumn{8}{|l|}{ Usual dose (daily) } \\
\hline Normal kidney function & $50 \mathrm{mg}$ & $100 \mathrm{mg}$ & $25 \mathrm{mg}$ & $5 \mathrm{mg}$ & $20 \mathrm{mg}$ & $5 \mathrm{mg}$ & $200 \mathrm{mg}$ \\
\hline Ccr $30-50 \mathrm{~mL} / \mathrm{min}$ & $25 \mathrm{mg}$ & $50 \mathrm{mg}$ & $12.5 \mathrm{mg}$ & $5 \mathrm{mg}$ & $20 \mathrm{mg}$ & $2.5 \mathrm{mg}$ & $200 \mathrm{mg}$ \\
\hline $\mathrm{Ccr}<30 \mathrm{~mL} / \mathrm{min}$ & $12.5 \mathrm{mg}$ & $50 \mathrm{mg}$ & $6.25 \mathrm{mg}$ & $5 \mathrm{mg}$ & $20 \mathrm{mg}$ & $2.5 \mathrm{mg}$ & $100 \mathrm{mg}$ \\
\hline \multicolumn{8}{|l|}{ Efficacy as monotherapy } \\
\hline Study duration (weeks) & 24 & 24 & 26 & 24 & 12 & 24 & 52 \\
\hline Baseline mean $\mathrm{HbA}_{\mathrm{Ic}}(\%)$ & 8.01 & 8.4 & 7.9 & 8.0 & 7.8 & 7.9 & 8.22 \\
\hline Change in $\mathrm{HbA}_{\mathrm{Ic}}(\%)$ & $-0.79 *$ & -0.7 & -0.59 & -0.69 & -0.8 & -0.46 & -0.63 \\
\hline Reference number & 11 & 12 & 13 & 14 & 15 & 16 & 17 \\
\hline
\end{tabular}

Notes: $\mathrm{IC}_{50}, T_{\max }, T_{1 / 2}$, the inhibition of plasma DPP-4 activity, and the increase in active GLP-I levels were based on the drug information of the corresponding agent published by the pharmaceutical company. ${ }^{*}$ The dose of sitagliptin was $100 \mathrm{mg}$ daily (QD).

Abbreviations: DPP-4, dipeptidyl peptidase-4; GLP-I, glucagon-like peptide-I; $I C_{50}$, half-maximal inhibitory concentration; $T_{\max }$, maximum drug concentration time; $T_{1 / 2}$, half-life period; Ccr, creatinine clearance rate.

the rate of prescription of DPP-4 inhibitors has increased markedly in recent years, reaching $50 \%-60 \%$. In contrast, the rate of prescription of insulin and biguanides has remained stable at approximately $30 \%$. This trend is similar to that observed for data obtained from databases in Japan ${ }^{1}$ and the United States. ${ }^{2}$ Therefore, it is not an exaggeration to state that the introduction of DPP-4 inhibi- tors has changed the treatment strategies for patients with type 2 diabetes.

Metformin, an OAD in the family of biguanides, is recognized to be the first-line drug among antidiabetic agents. ${ }^{3}$ Metformin administration is superior in the glucose-lowering effect for patients with type 2 diabetes, and regardless of the presence or absence of obesity, ${ }^{4}$ the prescription rate has

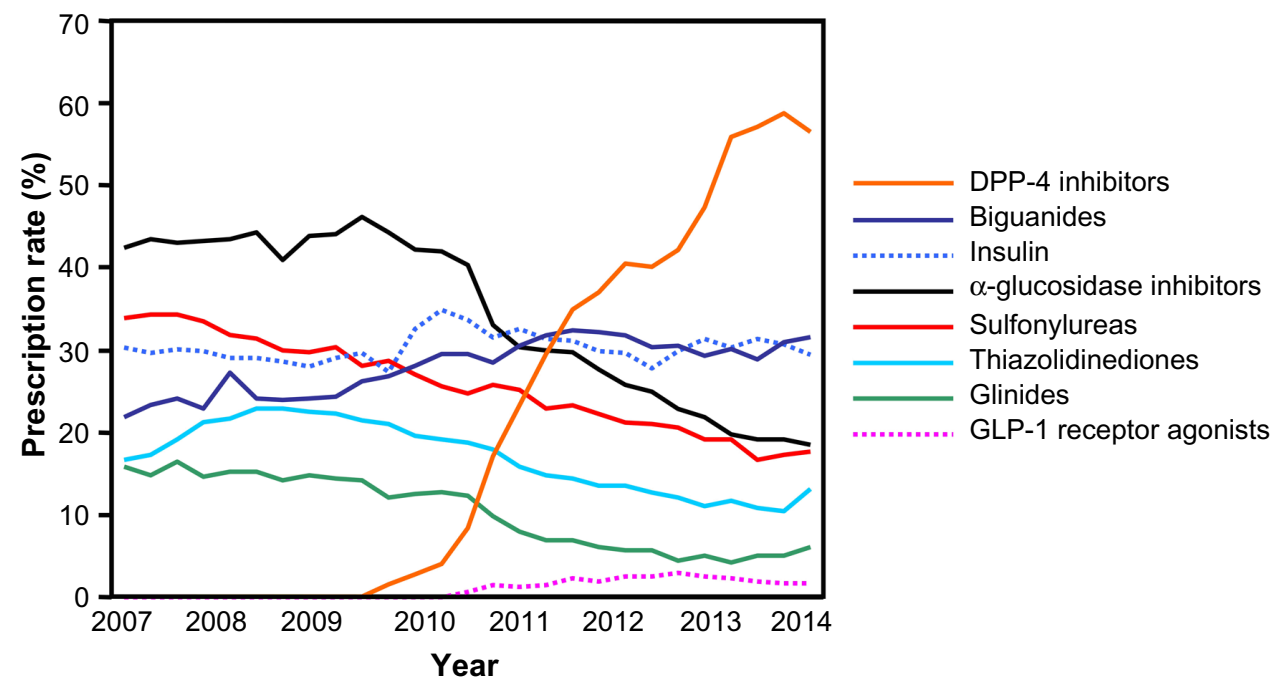

Figure I Prescription rates of antidiabetic agents.

Notes: The data were obtained from the database of Edogawa Hospital over three months. The prescription rate was calculated as the number of patients prescribed each class of antidiabetic agent divided by the total number of patients prescribed any type of antidiabetic agent. The number of patients prescribed $\alpha$-glucosidase inhibitors, sulfonylureas, thiazolidinediones, and glinides has declined continuously since the release of dipeptidyl peptidase-4 (DPP-4) inhibitors. The rate of prescription of dipeptidyl peptidase-4 inhibitors increased steadily to more than $50 \%$ in 2013 . In contrast, the use of insulin and biguanides has remained relatively stable at approximately $30 \%$. Copyright @2013. Journal of Japan Diabetes Society. Adapted from Ando S, Tsugami E, Suzuki S, et al. Recent trend in the prescription rates of antidiabetic agents in our facility. Journal of Japan Diabetes Society. 2013; 56 Suppl I: SI64. ${ }^{45}$

Abbreviations: DPP-4, dipeptidyl peptidase-4; GLP-I, glucagon-like peptide-I. 
remained unchanged at approximately $30 \%$ (Figure 1). This observation is considered to account for the relatively lower prescription rates among patients with type 2 diabetes who received consecutive treatments in our department, including many elderly subjects and individuals with renal impairment $^{5,6}$ who are contraindicated for biguanide administration..$^{7-9}$ Patients with type 2 diabetes tend to demonstrate a decreased renal function, as indicated by the estimated glomerular filtration rate and reduced endogenous insulin secretion along with the long-term duration of diabetes and aging (Figure 2). When selecting antidiabetic agents for patients with type 2 diabetes and renal dysfunction, it is necessary to use various OADs, including biguanides, sulfonylureas, and thiazolidinediones, carefully due to their side effects. On the other hand, it is a major advantage of DPP-4 inhibitors that agents in this class may be administered continuously, even in elderly subjects or patients with renal dysfunction, including those receiving maintenance dialysis. ${ }^{10}$

Whereas linagliptin and teneligliptin do not require dose adjustment, it is recommended that the dose of other DPP-4 inhibitors is reduced depending on the degree of renal dysfunction (Table 1). The lowering effect on the

$\mathrm{HbA}_{1 \mathrm{c}}$ level obtained in Phase III clinical trials ${ }^{11-17}$ does not differ significantly based on the drug. Anagliptin $\left(\right.$ Suiny $\left.^{\circledR}\right)$, a novel DPP-4 inhibitor, was developed by Sanwa Kagaku Kenkyusho Co, Ltd (Nagoya, Japan) and Kowa Pharmaceutical Co, Ltd (Tokyo, Japan) and has been available in Japan since November 2012. Because anagliptin was released relatively recently and this drug is not generally used in countries other than Japan (at the time of December 2014), there are only a small number of reports investigating the effects of anagliptin. However, it has been reported that anagliptin demonstrates serum lipid-lowering and antiatherogenic effects, which have not yet been observed in other DPP-4 inhibitors. We herein describe the effects of anagliptin primarily in Japanese patients with type 2 diabetes.

\section{Efficacy of anagliptin in patients with type 2 diabetes Efficacy of monotherapy after 12 weeks of treatment}

The recommended dose of anagliptin is $200 \mathrm{mg}$ daily $(100 \mathrm{mg}$, BID) in Japan. ${ }^{18}$ Because treatment with anagliptin exhibits

\section{B}
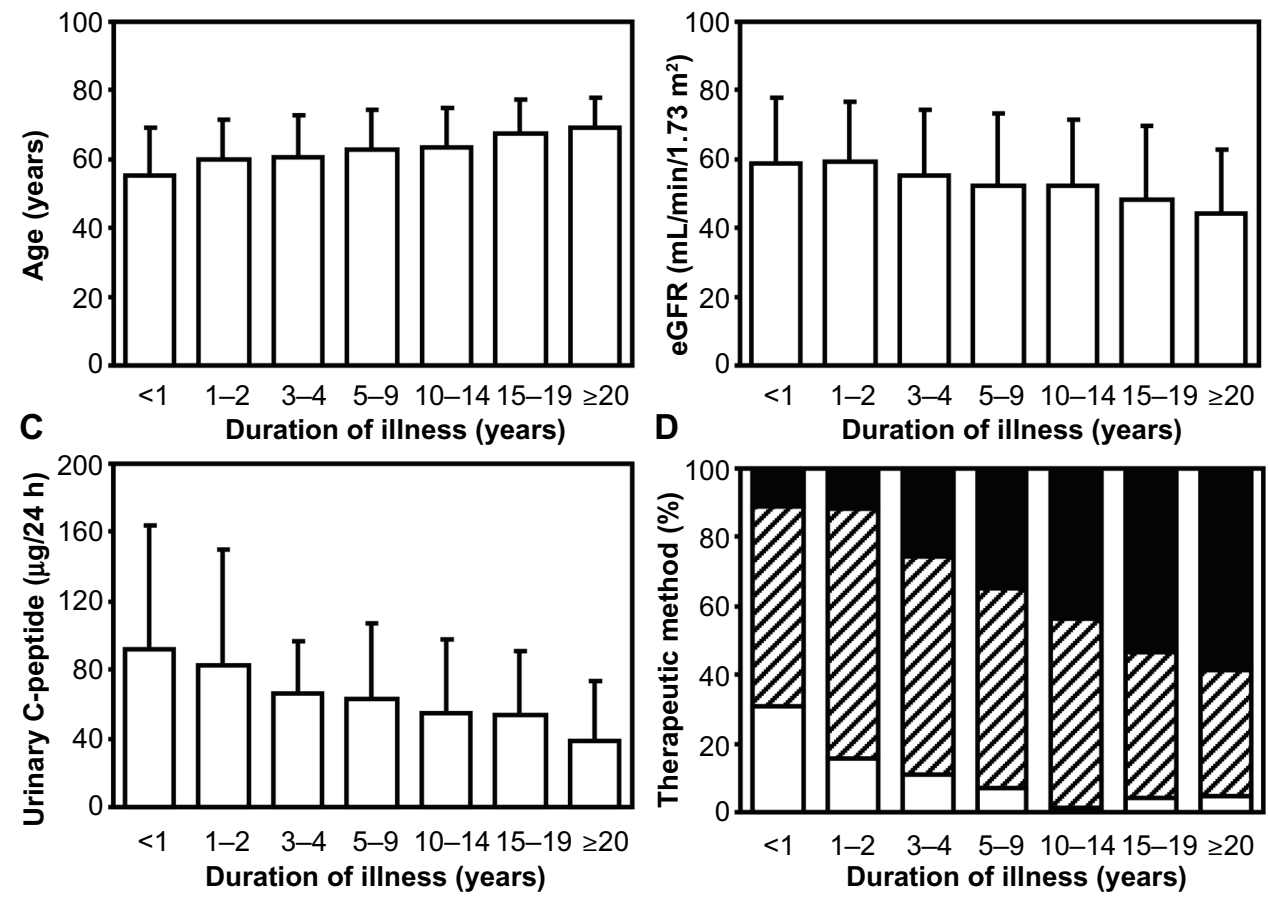

Figure 2 Data for (A) patient age, (B) estimated glomerular filtration rate (eGFR), (C) urinary C-peptide, and (D) therapeutic methods for type 2 diabetes among the groups divided according to the duration of illness.

Notes: A population of I,436 patients diagnosed with type 2 diabetes mellitus whose duration of illness was described in their medical records and who were treated for more than 6 months at the Department of Diabetes, Metabolism and Kidney Disease of Edogawa Hospital between 2008 and 201 I was examined. While the patient ages significantly increased in association with a longer duration of illness $(P<0.000 \mathrm{l}$, analysis of variance), both the estimated glomerular filtration rate ( $n=1436)$ and urinary C-peptide $(n=424)$ values were significantly reduced $(P<0.000$ I, analysis of variance). The proportion of patients receiving insulin treatment increased in association with a longer duration of illness $\left(P<0.000 \mathrm{I}, \chi^{2}\right.$ test). The data are shown as the means \pm standard deviation. Filled, hatched, and open bars indicate insulin (including the combination of insulin and oral antidiabetic agents), oral antidiabetic agents, and nonpharmacological therapies, respectively. 
dose-dependent improvements in the $\mathrm{HbA}_{1 \mathrm{c}}$ and blood glucose levels according to the results of a Phase II trial including a dose-ranging study (50-400 mg daily), ${ }^{19}$ increases in the dose up to $400 \mathrm{mg}$ daily (200 mg, BID) have been approved. ${ }^{18}$ In one study, the reduction in the $\mathrm{HbA}_{1 \mathrm{c}}$ values from baseline after 12 weeks monotherapy with $200 \mathrm{mg}(n=69)$ and $400 \mathrm{mg}(n=68)$ of daily anagliptin was $0.75 \% \pm 0.50 \%$ and $0.82 \% \pm 0.46 \%$, respectively, and more than $40 \%$ of the subjects receiving anagliptin at a dose of $200 \mathrm{mg}$ or $400 \mathrm{mg}$ daily achieved an $\mathrm{HbA}_{1 \mathrm{c}}$ level below 6.9\%. ${ }^{19}$ In another Phase II/III trial, the administration of monotherapy for 12 weeks demonstrated a reduction of $0.66 \% \pm 0.50 \%$ and $0.75 \% \pm 0.55 \%$ in the $\mathrm{HbA}_{1 \mathrm{c}}$ levels with $200 \mathrm{mg}(n=63)$ and $400 \mathrm{mg}(n=58)$ of daily anagliptin, respectively. ${ }^{20}$ The differences in the $\mathrm{HbA}_{1 \mathrm{c}}$ levels versus the placebo group among the subjects receiving $200 \mathrm{mg}$ and $400 \mathrm{mg}$ of anagliptin daily were $-0.72 \%$ and $-0.82 \%$, respectively. ${ }^{20}$

According to a pooled analysis of the data obtained from Phase II and Phase II/III trials, the goal achievement rate of an $\mathrm{HbA}_{1 \mathrm{c}}$ level less than $7.0 \%$ was $51.1 \%$ in the group treated with anagliptin at a dose of $200 \mathrm{mg}$ (100 mg, BID) at 12 weeks, which was significantly superior to that attained with voglibose, an $\alpha$-glucosidase inhibitor. ${ }^{21}$

\section{Long-term efficacy of monotherapy}

$\mathrm{Kaku}^{17}$ reported that the use of monotherapy with anagliptin at a daily dose of $200 \mathrm{mg}$ (with dose increases up to $400 \mathrm{mg}$ permitted if the glucose-lowering effect was insufficient) showed continuous improvements in the $\mathrm{HbA}_{1 \mathrm{c}}$ levels over 52 weeks in 150 patients with type 2 diabetes whose blood glucose levels were poorly controlled $\left(6.9 \% \leq \mathrm{HbA}_{1 \mathrm{c}}<10.5 \%\right)$ even after receiving nonpharmacological therapy. The changes in the $\mathrm{HbA}_{1 \mathrm{c}}$, fasting blood glucose, and postprandial 2 -h blood glucose levels were $-0.63 \% \pm 0.85 \%$ (baseline value: $8.22 \% \pm 1.06 \%$ ), $-12.5 \pm 32.2 \mathrm{mg} / \mathrm{dL}$ (baseline value: $166.1 \pm 38.4 \mathrm{mg} / \mathrm{dL})$, and $-31.0 \pm 47.8 \mathrm{mg} / \mathrm{dL}$ (baseline value: $255.1 \pm 60.3 \mathrm{mg} / \mathrm{dL}$ ), respectively. Furthermore, improvements were noted in the levels of 1,5-AG, glycoalbumin, serum insulin, proinsulin, homeostatic model assessment- $\beta$, total cholesterol, and low-density lipoprotein (LDL)-cholesterol.

\section{Combination therapy}

The changes in the $\mathrm{HbA}_{1 \mathrm{c}}$ levels observed in a Phase III trial $^{22}$ of anagliptin as an add-on therapy to $\alpha$-glucosidase inhibitors (acarbose $20.2 \%$, voglibose $43.6 \%$, and miglitol $36.2 \%$ ), biguanides (metformin), sulfonylureas (glimepiride $73.5 \%$, gliclazide $10.3 \%$, and glibenclamide $16.2 \%$ ), and thiazolidinediones (pioglitazone) are shown in Table 2. In this trial, treatment with anagliptin at a dose of $200 \mathrm{mg}$ daily (100 mg, BID) or a placebo was administered for an initial 12 weeks in patients with type 2 diabetes whose $\mathrm{HbA}_{1 \mathrm{c}}$ levels were between $6.9 \%$ and $10.4 \%$, even after treatment with other OADs. Anagliptin was subsequently administered at a dose of $200 \mathrm{mg}$ daily for 40 weeks in both groups. Increases in the dose of anagliptin up to $400 \mathrm{mg}$ daily (200 mg, BID) were allowed if the $\mathrm{HbA}_{1 \mathrm{c}}$ level was $>6.9 \%$ at 28 weeks. Consequently, the improvements in parameters indicating glycemic control at 12 weeks were significantly greater in the anagliptin/anagliptin group than in the placebo/anagliptin group, regardless of whether OADs were administered before the trial. Furthermore, the levels of $\mathrm{HbA}_{1 \mathrm{c}}$, fasting blood glucose, and postprandial blood glucose were significantly decreased at 52 weeks compared with the baseline values.

As it has been reported that metformin increases the plasma-active GLP-1 in humans ${ }^{23}$ via the inhibitory effects of DPP-4, ${ }^{24}$ combination therapy with anagliptin and metformin is considered to be suitable for the treatment of type 2 diabetes based on the enhanced endogenous GLP-1 activity. Furthermore, combination therapy with anagliptin and $\alpha$-glucosidase inhibitors also has advantages, as it has been reported that GLP-1 secretion is prolonged by acarbose. ${ }^{25}$ On the other hand, the maximum drug concentration $\left(C_{\max }\right)$ and area under the blood concentration-time curve (AUC) from time zero to $24 \mathrm{~h}$ after dosing $\left(\mathrm{AUC}_{0-24 \mathrm{~h}}\right)$ for anagliptin are reduced with the concomitant administration with miglitol, ${ }^{26}$ whereas both the $C_{\max }$ and $\mathrm{AUC}_{0-24 \mathrm{~h}}$ values for anagliptin are elevated in subjects under treatment with the combination therapy consisting of metformin and anagliptin. ${ }^{27}$ The degree of improvement in glycemic control achieved with combination therapy using anagliptin and sulfonylureas appears to be lower than that attained with $\alpha$-glucosidase inhibitors, biguanides, or thiazolidinediones. Nevertheless, there is concern regarding the potential for hypoglycemia in patients with type 2 diabetes treated with DPP-4 inhibitors and sulfonyulureas. ${ }^{28}$ This issue should be investigated in detail in a real clinical setting.

According to the results of a pooled analysis of the data obtained from Phase II and Phase II/III trials, ${ }^{21}$ the goal achievement rates of an $\mathrm{HbA}_{1 \mathrm{c}}$ level less than $7.0 \%$ at 12 weeks in patients receiving combination therapy with anagliptin and other OADs are 40.3\%, 39.4\%, 30.0\%, and $34.8 \%$ for $\alpha$-glucosidase inhibitors, thiazolidinediones, sulfonylureas, and biguanides, respectively. 
Table 2 Changes in the levels of $\mathrm{HbA}_{1 \mathrm{c}}$, fasting blood glucose, and postprandial blood glucose in the groups treated with combination therapy with anagliptin and other oral antidiabetic agents in a Phase III clinical trial

\begin{tabular}{|c|c|c|c|c|}
\hline & Parameters & Treatment group & 12 weeks (n) & 52 weeks $(n)$ \\
\hline \multirow[t]{6}{*}{$\alpha$-gucosidase inhibitors } & $\mathrm{HbA}_{\mathrm{Ic}}(\%)$ & Placebo/anagliptin & $0.12 \pm 0.58(32)$ & $-0.87 \pm 0.81(94)^{\# \#}$ \\
\hline & & Anagliptin/anagliptin & $-0.83 \pm 0.56(62)^{* * *}$ & \\
\hline & Fasting blood glucose (mg/dL) & Placebo/anagliptin & $5.9 \pm 39.5(32)$ & $-15.6 \pm 29.3(94)^{\ldots \#}$ \\
\hline & & Anagliptin/anagliptin & $-18.5 \pm 25.7(62)^{* * *}$ & \\
\hline & Postprandial blood glucose (mg/dL) & Placebo/anagliptin & $5.9 \pm 47.5(32)$ & $-38.5 \pm 48.9(92)^{\ldots \#}$ \\
\hline & & Anagliptin/anagliptin & $-43.1 \pm 38.3(62)^{* * *}$ & \\
\hline \multirow[t]{6}{*}{ Biguanides } & $\mathrm{HbA}_{\mathrm{Ic}}(\%)$ & Placebo/anagliptin & $0.45 \pm 0.91(36)$ & $-0.67 \pm 1.15(104)^{\# \#}$ \\
\hline & & Anagliptin/anagliptin & $-0.62 \pm 0.67(69)^{* * *}$ & \\
\hline & Fasting blood glucose (mg/dL) & Placebo/anagliptin & $10.9 \pm 35.2(36)$ & $-15.0 \pm 37.5(104)^{\ldots \ldots 1}$ \\
\hline & & Anagliptin/anagliptin & $-13.6 \pm 26.8(69)^{* * *}$ & \\
\hline & Postprandial blood glucose (mg/dL) & Placebo/anagliptin & $15.6 \pm 43.5(36)$ & $-24.9 \pm 56.7(100)^{\ldots}$ \\
\hline & & Anagliptin/anagliptin & $-30.4 \pm 45 . I(67)^{* * *}$ & \\
\hline \multirow[t]{6}{*}{ Sulfonylureas } & $\mathrm{HbA}_{\mathrm{Ic}}(\%)$ & Placebo/anagliptin & $0.24 \pm 0.59(45)$ & $-0.36 \pm 0.84(135)^{\ldots \#}$ \\
\hline & & Anagliptin/anagliptin & $-0.53 \pm 0.48(90) * * *$ & \\
\hline & Fasting blood glucose (mg/dL) & Placebo/anagliptin & $2.0 \pm 27.8(45)$ & $-6.7 \pm 27.0(135)^{\#}$ \\
\hline & & Anagliptin/anagliptin & $-10.3 \pm 29.2(90)^{*}$ & \\
\hline & Postprandial blood glucose (mg/dL) & Placebo/anagliptin & $1.9 \pm 40.6(45)$ & $-8.7 \pm 43.5(134)^{\#}$ \\
\hline & & Anagliptin/anagliptin & $-25.1 \pm 40.1(90)^{* * *}$ & \\
\hline \multirow[t]{6}{*}{ Thiazolidinediones } & $\mathrm{HbA}_{\mathrm{Ic}}(\%)$ & Placebo/anagliptin & $0.32 \pm 0.67(31)$ & $-0.88 \pm 0.89(102)^{\ldots \#}$ \\
\hline & & Anagliptin/anagliptin & $-0.52 \pm 0.68(7 \mathrm{I})^{* * *}$ & \\
\hline & Fasting blood glucose (mg/dL) & Placebo/anagliptin & $6.3 \pm 2 I .3(3 \mathrm{I})$ & $-19.8 \pm 26.9(102)^{\ldots \ldots}$ \\
\hline & & Anagliptin/anagliptin & $-15.9 \pm 34.9(7 \mid)^{* *}$ & \\
\hline & Postprandial blood glucose (mg/dL) & Placebo/anagliptin & $10.5 \pm 38.1(31)$ & $-42.4 \pm 50.3(100)^{\ldots}$ \\
\hline & & Anagliptin/anagliptin & $-34.4 \pm 52.7(69)^{* * *}$ & \\
\hline
\end{tabular}

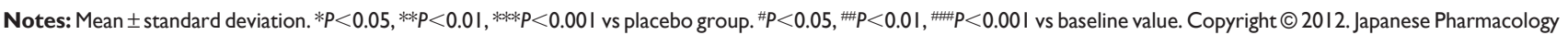
and Therapeutics. Adapted from Kaku K. Efficacy and safety of anagliptin add-on therapy in Japanese patients with type 2 diabetes. Jpn Pharmacol Ther. 20I2;40(9):745-770.22

\section{Daily blood glucose profile}

Uchino and $\mathrm{Kaku}^{29}$ investigated the daily blood glucose profiles using continuous glucose monitoring in 20 patients with type 2 diabetes under treatment with $200 \mathrm{mg}$ of anagliptin $(100 \mathrm{mg}$, BID) or $50 \mathrm{mg}$ of sitagliptin (QD) in an open-label, two-period crossover study. The area under the curve for the blood glucose level $(4,421.9 \pm 1,187.0 \mathrm{mg} \mathrm{h} / \mathrm{dL})$, average 24-h blood glucose level $(184.10 \pm 49.39 \mathrm{mg} / \mathrm{dL}), M$-value $(29.4 \pm 32.7 \mathrm{mg} / \mathrm{dL})$, and mean amplitude of glycemic excursion $(104.97 \pm 32.71 \mathrm{mg} /$ $\mathrm{dL}$ ) during the anagliptin administration period were significantly lower than the corresponding values obtained in the control period $(4,906.0 \pm 924.9 \mathrm{mg} \mathrm{h} / \mathrm{dL}, 204.25 \pm 38.53 \mathrm{mg} /$ $\mathrm{dL}, 39.54 \pm 26.27 \mathrm{mg} / \mathrm{dL}$, and $126.50 \pm 19.03 \mathrm{mg} / \mathrm{dL}$, respectively), whereas these parameters were not significantly different from the corresponding values noted during the sitagliptin administration period $(4,469.2 \pm 1,125.7 \mathrm{mg}$ $\mathrm{h} / \mathrm{dL}, 186.06 \pm 46.83 \mathrm{mg} / \mathrm{dL}, 30.35 \pm 12.42 \mathrm{mg} / \mathrm{dL}$, and $110.35 \pm 30.95 \mathrm{mg} / \mathrm{dL}$, respectively).

\section{Lipid-lowering effect}

Managing the serum lipid concentrations is important in patients with type 2 diabetes as dyslipidemia is an important risk factor for diabetic macroangiopathy in Japanese subjects. ${ }^{30}$ According to a pooled analysis of data obtained from Phase III trials, the serum LDL-cholesterol, triglyceride, total cholesterol and non-high-density lipoprotein (HDL)-cholesterol levels significantly improved after the administration of anagliptin at a dose of $200 \mathrm{mg}$ (100 mg, BID) or $400 \mathrm{mg}$ (200 mg, BID) (Table 3) ${ }^{31}$ Meanwhile, the serum concentrations of HDL-cholesterol increased significantly in the subjects with an HDL-cholesterol level less than $40 \mathrm{mg} / \mathrm{dL}$ and decreased in the entire patient population. These observations suggest that there is an additional mechanism independent of the lipid-lowering effect of these drugs that occurs secondary to improvements in the blood glucose level, as the correlation coefficient between the change in the $\mathrm{HbA}_{1 \mathrm{c}}$ level and the LDL-cholesterol $(r=0.112, P=0.003)$ or triglyceride $(r=0.075, P=0.07)$ levels was rather small. Therefore, treatment with anagliptin is expected to prevent atherosclerotic diseases in addition to diabetic microangiopathy by improving glycemic control in patients with type 2 diabetes.

\section{Antiatherogenic effect}

DPP-4 inhibitors are thought to reduce the risk of cardiovascular events, particularly myocardial infarction, in patients with 
Table 3 Changes in the serum lipid concentrations in a Phase III trial

\begin{tabular}{|c|c|c|c|c|}
\hline & Baseline & 12 weeks & 52 weeks & $P$ \\
\hline \multicolumn{5}{|l|}{ LDL-cholesterol } \\
\hline$n$ & 577 & 556 & 388 & \\
\hline $\begin{array}{l}\text { Measured } \\
\text { value }(\mathrm{mg} / \mathrm{dL})\end{array}$ & $|2| .1 \pm 1.2$ & $117.0 \pm 1.2$ & $111.9 \pm 1.3$ & $<0.001$ \\
\hline $\begin{array}{l}\text { Amount of } \\
\text { change }(\mathrm{mg} / \mathrm{dL})\end{array}$ & - & $-3.6 \pm 0.9$ & $-9.7 \pm 1.1$ & \\
\hline Rate of change (\%) & - & $-1.8 \pm 0.7$ & $-6.5 \pm 0.9$ & \\
\hline \multicolumn{5}{|l|}{ Triglycerides } \\
\hline$n$ & 585 & 571 & 399 & \\
\hline $\begin{array}{l}\text { Measured } \\
\text { value }(\mathrm{mg} / \mathrm{dL})\end{array}$ & 119.0 & 115.0 & 107 & 0.005 \\
\hline $\begin{array}{l}\text { Amount of } \\
\text { change }(\mathrm{mg} / \mathrm{dL})\end{array}$ & - & -5.0 & -5.0 & \\
\hline Rate of change (\%) & - & -4.7 & -5.4 & \\
\hline \multicolumn{5}{|l|}{ Total cholesterol } \\
\hline$n$ & 585 & 571 & 399 & \\
\hline $\begin{array}{l}\text { Measured } \\
\text { value }(\mathrm{mg} / \mathrm{dL})\end{array}$ & $204.8 \pm 1.4$ & $200.5 \pm 1.4$ & $195.1 \pm 1.6$ & $<0.001$ \\
\hline $\begin{array}{l}\text { Amount of } \\
\text { change }(\mathrm{mg} / \mathrm{dL})\end{array}$ & - & $-4.2 \pm 1.0$ & $-10.1 \pm 1.3$ & \\
\hline Rate of change (\%) & - & $-1.5 \pm 0.5$ & $-4.1 \pm 0.6$ & \\
\hline \multicolumn{5}{|l|}{ HDL-cholesterol } \\
\hline$n$ & 585 & 571 & 399 & \\
\hline $\begin{array}{l}\text { Measured } \\
\text { value }(\mathrm{mg} / \mathrm{dL})\end{array}$ & $56.2 \pm 0.6$ & $55.9 \pm 0.6$ & $55.9 \pm 0.7$ & $<0.001$ \\
\hline $\begin{array}{l}\text { Amount of } \\
\text { change }(\mathrm{mg} / \mathrm{dL})\end{array}$ & - & $-0.4 \pm 7.7$ & $-0.1 \pm 0.4$ & \\
\hline Rate of change (\%) & - & $0.2 \pm 0.6$ & $0.6 \pm 0.6$ & \\
\hline \multicolumn{5}{|c|}{ HDL-cholesterol (in subgroup with baseline value $<40 \mathrm{mg} / \mathrm{dL}$ ) } \\
\hline$n$ & 63 & 61 & 43 & \\
\hline $\begin{array}{l}\text { Measured } \\
\text { value }(\mathrm{mg} / \mathrm{dL})\end{array}$ & $34.5 \pm 0.5$ & $36.1 \pm 0.7$ & $37.6 \pm 0.8$ & $<0.001$ \\
\hline $\begin{array}{l}\text { Amount of } \\
\text { change }(\mathrm{mg} / \mathrm{dL})\end{array}$ & - & $1.6 \pm 0.6$ & $2.3 \pm 0.6$ & \\
\hline Rate of change (\%) & - & $5.4 \pm 2.0$ & $6.9 \pm 1.9$ & \\
\hline \multicolumn{5}{|l|}{ Non HDL-cholesterol } \\
\hline$n$ & 585 & 571 & 399 & \\
\hline $\begin{array}{l}\text { Measured } \\
\text { value }(\mathrm{mg} / \mathrm{dL})\end{array}$ & $\mid 48.6 \pm 1.4$ & $144.5 \pm 1.5$ & $139.2 \pm 1.5$ & $<0.001$ \\
\hline $\begin{array}{l}\text { Amount of } \\
\text { change }(\mathrm{mg} / \mathrm{dL})\end{array}$ & - & $-3.9 \pm 0.9$ & $-10.0 \pm 1.3$ & \\
\hline Rate of change (\%) & - & $-1.7 \pm 0.7$ & $-5.2 \pm 0.8$ & \\
\hline
\end{tabular}

Notes: Mean \pm SE. The $P$-value was measured according to a repeated-measures analysis of variance. Copyright $\odot$ 2012. Japanese Pharmacology and Therapeutics. Adapted from Kaku K. Effects of anagliptin on serum lipids in Japanese patients with type 2 diabetes - a pooled analysis of long-term therapy with anagliptin. Jpn Pharmacol Ther. 201 2;40(9):77I-784. ${ }^{31}$

Abbreviations: LDL, low-density lipoprotein; HDL, high-density lipoprotein.

type 2 diabetes..$^{32}$ Recently, Ervinna et a ${ }^{33}$ reported that the administration of anagliptin attenuates atherosclerosis secondary to suppression of the proliferation of vascular smooth muscles and monocyte inflammatory reactions in apo-E-deficient mice, an animal model of progressive atherosclerosis.

Kakuda et al ${ }^{34}$ showed that oxidative stress markers, such as urinary $8-\mathrm{OHdG}$ and serum high-sensitivity-CRP, are ameliorated and the plasma level of high-molecular weight adiponectin, which has an antiatherogenic effect, increases after the initiation of therapy with $200 \mathrm{mg}$ of anagliptin daily, in addition to observed improvements in blood glucose control and the serum LDL-cholesterol, triglyceride, non-HDLcholesterol and remnant-like particle-cholesterol levels. Imai et $\mathrm{al}^{35}$ also reported that treatment with anagliptin or miglitol reduces the oral sucrose load-inducible gene expression of inflammatory cytokines, such as interleukin- $1 \beta$ and interleukin-18, and tumor necrosis factor- $\alpha$, in the peripheral leukocytes of Otsuka Long-Evans Tokushima fatty rats. However, it remains unclear which of these anti-inflammatory effects is specifically caused by anagliptin and which occurs secondary to improvements in postprandial hyperglycemia, which is commonly seen in patients with glucose impairment.

Mimura et $\mathrm{al}^{36}$ demonstrated that treatment with anagliptin facilitates the restoration of mucosal damage in mice exhibiting experimental colitis induced by dextran sulfate sodium. The authors suggested the possibility of applying anagliptin administration as a novel therapeutic approach for the treatment of inflammatory bowel disease. Further investigations are required to confirm this hypothesis in both basic and clinical research.

\section{Safety and patient acceptability Safety in preclinical trials}

The frequency of adverse effects (AEs) is not significantly different between subjects administered anagliptin and those administered a placebo according to the results of a Phase II trial performed over 12 weeks. ${ }^{19}$ Most AEs were mild and no events resulting from increases in the dose of anagliptin were observed.

AEs were noted in $23.5 \%$ (19 of 81 patients) and $15.7 \%$ (11 of 70 patients) of subjects receiving preprandial and postprandial administration, respectively, during treatment with long-term monotherapy consisting of $200-400 \mathrm{mg}$ of daily anagliptin (100-200 mg, BID) for 52 weeks. ${ }^{17}$ In that study, the complications observed in more than $2 \%$ of the subjects included constipation (4.9\%) and gastritis (4.9\%), whereas only one patient $(0.7 \%)$ showed mild hypoglycemia. Although statistically significant changes were detected in some laboratory data and vital signs compared with the baseline values, they were not considered to be meaningful due to the small variation within the normal ranges. Furthermore, no serious AEs were reported in another Phase III trial investigating the effects of combination therapy with anagliptin and other OADs. ${ }^{22}$ Side effects observed in more than $2 \%$ of the subjects in that trial are shown in Table 4. Because the frequency of hypoglycemia was relatively high in the 
Table 4 Side effects observed in more than $2 \%$ of subjects treated with anagliptin and other oral antidiabetic agents in a Phase III trial in Japan

\begin{tabular}{lllll}
\hline & Biguanides & $\alpha$-Glucosidase inhibitors & Sulfonylureas & Thiazolidinediones \\
\hline$n$ & 104 & 94 & 135 & 102 \\
Total number & $25(24.0 \%)$ & $22(23.4 \%)$ & $43(31.9 \%)$ & $23(22.5 \%)$ \\
$\begin{array}{l}\text { Abdominal fullness } \\
\text { Constipation }\end{array}$ & $3(2.9 \%)$ & $2(2.1 \%)$ & & $2(2.0 \%)$ \\
$\begin{array}{l}\text { Nasopharyngitis } \\
\text { ALT elevation }\end{array}$ & $7(3.8 \%)$ & $2(2.1 \%)$ & $7(5.2 \%)$ & $2(2.0 \%)$ \\
AST elevation & $3(2.9 \%)$ & & $6(4.4 \%)$ & \\
$\begin{array}{l}\text { Serum amylase elevation } \\
\text { rGTP elevation }\end{array}$ & $3(2.9 \%)$ & & & $3(2.2 \%)$ \\
$\begin{array}{l}\text { Hematocrit reduction } \\
\text { Hemoglobin reduction }\end{array}$ & & $3(4.2 \%)$ & & \\
$\begin{array}{l}\text { Red blood cell count reduction } \\
\text { Occult blood in stool }\end{array}$ & & $4(4.3 \%)$ & & \\
Hypoglycemia & $5(4.8 \%)$ & $2(2.1 \%)$ & $5(3.7 \%)$ & $10(7.4 \%)$ \\
\hline
\end{tabular}

Note: Copyright (C) 2012. Japanese Pharmacology and Therapeutics. Adapted from Kaku K. Efficacy and safety of anagliptin add-on therapy in Japanese patients with type 2 diabetes. Jpn Pharmacol Ther. 2012;40(9):745-770. ${ }^{22}$

Abbreviations: ALT, aspartate aminotransferase; AST, alanine transaminase; $\gamma \mathrm{GTP}, \gamma$-glutamyltransferase.

sulfonylurea group, it is important to pay attention to the potential for hypoglycemia in patients receiving combination therapy with anagliptin and sulfonylureas, as described earlier. Other than hypoglycemia, no side effects of concern have been documented. Therefore, treatment with anagliptin is considered to be superior in terms of safety and tolerability for both monotherapy and combination therapy.

\section{Safety in the real clinical setting}

One case of hypokalemia and muscle weakness was reported as serious side effects of anagliptin during postmarketing surveillance by Sanwa Kagaku Kenkyusho Co, Ltd. ${ }^{37}$ In addition, a small number of nonserious events, including gastrointestinal symptoms $(n=9)$ and somnolence $(n=3)$, were observed among approximately 20,000 diabetic patients treated with anagliptin for 6 months after the drug's release. The case of a 60 -year-old Japanese male with type 2 diabetes complicated by the onset of angioedema 4 days after the initiation of anagliptin was reported by Hamasaki and Yanai. ${ }^{38}$ Although an increased risk of angioedema has been described in patients using both DPP-4 inhibitors and angiotensin-converting enzyme inhibitors, ${ }^{39}$ no medications other than anagliptin were given in this case. Because DPP-4 influences the rate of degradation of bradykinin, the authors suggested that DPP-4 inhibitors may increase the half-life of bradykinin.

Currently, the biggest clinical concern with DPP-4 inhibitors is the increased incidence of new heart failure with these medications. ${ }^{40,41}$ Although alogliptin, another DPP-4 inhibitor, did not demonstrate an increased risk for cardiovascular disease and heart failure, ${ }^{42,43}$ there have not yet been any studies on the association between anagliptin treatment and heart failure.

\section{Safety in patients with renal impairment}

The ratio of AUC from time zero to infinity after dosing $\left(\mathrm{AUC}_{0-\infty}\right)$ in subjects with a normal kidney function following the single administration of anagliptin at a dose of $400 \mathrm{mg}$ is $1.65 \mathrm{ng} \mathrm{h} / \mathrm{mL}, 1.76 \mathrm{ng} \mathrm{h} / \mathrm{mL}, 2.70 \mathrm{ng} \mathrm{h} / \mathrm{mL}$, and $3.22 \mathrm{ngh} / \mathrm{mL}$ for those with mild renal impairment $(n=6,60 \mathrm{~mL} /$ $\min / 1.73 \mathrm{~m}^{2} \leq$ creatinine clearance $<90 \mathrm{~mL} / \mathrm{min} / 1.73 \mathrm{~m}^{2}$ ), moderate renal impairment $\left(n=6,30 \mathrm{~mL} / \mathrm{min} / 1.73 \mathrm{~m}^{2} \leq\right.$ creatinine clearance $<60 \mathrm{~mL} / \mathrm{min} / 1.73 \mathrm{~m}^{2}$ ), severe renal impairment $\left(n=6,15 \mathrm{~mL} / \mathrm{min} / 1.73 \mathrm{~m}^{2} \leq\right.$ creatinine clearance $<30 \mathrm{~mL} / \mathrm{min} / 1.73 \mathrm{~m}^{2}$ ), and end-stage kidney disease under maintenance hemodialysis $(n=6)$, respectively. ${ }^{18}$ Because AUC values are greater in the progressive stages of renal dysfunction, the dose of anagliptin is usually reduced to $100 \mathrm{mg}$ once daily in patients with severe renal impairment (Table 1). There are currently no studies investigating safety or patient acceptability in subjects with type 2 diabetes and renal impairment. However, treatment with anagliptin may have a glucose-lowering effect at half-doses in patients with renal dysfunction, similarly to linagliptin, ${ }^{44}$ which does not require dose reduction.

\section{Conclusion}

Anagliptin is thought to be a potent DPP-4 inhibitor demonstrating safety and tolerability in patients with type 2 diabetes. Treatment with anagliptin improves glycemic control for both monotherapy and combination therapy, and it is possible that anagliptin prevents atherosclerotic disease as well as diabetic 
microangiopathy. However, there are too few reports of the effects of anagliptin. There is currently no data on the use of this drug for more than 1 year or the application of combination therapy with anagliptin and insulin. Additionally, the antiatherogenic effect of anagliptin was not supported by any comprehensive clinical data. Further investigation is therefore necessary to clarify the safety, efficacy, and patient acceptability of anagliptin in subjects with type 2 diabetes.

\section{Acknowledgment}

The authors thank Tomoko Koyanagi in the secretarial section of Edogawa Hospital for her valuable help with data collection.

\section{Disclosure}

The authors report no conflicts of interest in this work.

\section{References}

1. Kohro T, Yamazaki T, Sato H, et al. Trends in antidiabetic prescription patterns in Japan from 2005 to 2011. Int Heart J. 2013;54(2):93-97.

2. Turner LW, Nartey D, Stafford RS, Singh S, Alexander GC. Ambulatory treatment of type 2 diabetes in the US, 1997-2012. Diabetes Care. 2014;37(4):985-992.

3. American Diabetes Association. Standards of medical care in diabetes 2014. Diabetes Care. 2014;37(Suppl 1):S14-S80.

4. Ito H, Ishida H, Takeuchi $\mathrm{Y}$, et al. Long-term effect of metformin on blood glucose control in non-obese patients with type 2 diabetes mellitus. Nutr Metab. 2010;201(7):83.

5. Ito $\mathrm{H}$, Takeuchi $\mathrm{Y}$, Ishida $\mathrm{H}$, et al. High frequencies of diabetic microand macroangiopathies in patients with type 2 diabetes mellitus with decreased estimated glomerular filtration rate and normoalbuminuria. Nephrol Dial Transplant. 2010;25(4):1161-1167.

6. Ito H, Oshikiri K, Mifune M, et al. The usefulness of the revised classification for chronic kidney disease by the KDIGO for determining the frequency of diabetic micro- and macroangiopathies in Japanese patients with type 2 diabetes mellitus. $J$ Diabetes Complications. 2012;26(4):286-290.

7. National Kidney Foundation. KDOQI clinical practice guideline for diabetes and CKD: 2012 update. Am J Kidney Dis. 2012;60(5):850-886.

8. Tuttle KR, Bakris GL, Bilous RW, et al. Diabetic kidney disease: a report from an ADA consensus conference. Diabetes Care. 2014;37(10): 2864-2883.

9. Japan Diabetes Society, editors. Treatment Guide for Diabetes 2012-2013. Tokyo: Bunkodo; 2012.

10. Ito H, Mifune M, Matsuyama E, et al. Vildagliptin is effective for glycemic control in diabetic patients undergoing either hemodialysis or peritoneal dialysis. Diabetes Ther. 2013;4(2):321-329.

11. Aschner P, Kipnes MS, Lunceford JK, et al; Sitagliptin Study 021 Group. Effect of the dipeptidyl peptidase-4 inhibitor sitagliptin as monotherapy on glycemic control in patients with type 2 diabetes. Diabetes Care. 2006;29(12):2632-2637.

12. Pi-Sunyer FX, Schweizer A, Mills D, Dejager S. Efficacy and tolerability of vildagliptin monotherapy in drug-naive patients with type 2 diabetes. Diabetes Res Clin Pract. 2007;76(1):132-138.

13. DeFronzo RA, Fleck PR, Wilson CA, Mekki Q; Alogliptin Study 010 Group. Efficacy and safety of the dipeptidyl peptidase-4 inhibitor alogliptin in patients with type 2 diabetes and inadequate glycemic control: a randomized, double-blind, placebo-controlled study. Diabetes Care. 2008;31(12):2315-2317.
14. Del Prato S, Barnett AH, Huisman H, Neubacher D, Woerle HJ, Dugi KA. Effect of linagliptin monotherapy on glycaemic control and markers of $\beta$-cell function in patients with inadequately controlled type 2 diabetes: a randomized controlled trial. Diabetes Obes Metab. 2011;13(3): 258-267.

15. Kadowaki T, Kondo K. Efficacy, safety and dose-response relationship of teneligliptin, a dipeptidyl peptidase-4 inhibitor, in Japanese patients with type 2 diabetes mellitus. Diabetes Obes Metab. 2013;15(9):810-818.

16. Rosenstock J, Aguilar-Salinas C, Klein E, et al; CV181-011 Study Investigators. Effect of saxagliptin monotherapy in treatment-naïve patients with type 2 diabetes. Curr Med Res Opin. 2009;25(10):2401-2411.

17. Kaku K. Efficacy and safety of long-term monotherapy with anagliptin in Japanese patients with type 2 diabetes - a multi-centre. Randomised, open-label, parallel-group study (administered before meals vs after meals). Jpn Pharmacol Ther. 2012;40(10):733-744. Japanese [Abstract in English].

18. Sanwa Kagaku Kenkyusho Co, Ltd 2015. Available from: http://med. skk-net.com/resources/show? colum=refference_files\&field $=$ doc mng\&num=1\&thread_id=d2a5fafb-796e-4409-9986-2d4ba2f5b2ad. Accessed January 25, 2015. [Japanese].

19. Kaku K. Dose-ranging study of anagliptin in Japanese patients with type 2 diabetes - a multi-centre, randomized, placebo-controlled, double-blind, parallel-group study. Jpn Pharmacol Ther. 2012;40(11): 944-973. Japanese [Abstract in English].

20. Kaku K. Efficacy and safety of anagliptin in Japanese patients with type 2 diabetes - a multi-centre, randomized, placebo-controlled, double-blind, parallel-group study. Jpn Pharmacol Ther. 2012;40(11):985-995. Japanese [Abstract in English].

21. Kaku K. Effects of anagliptin on the new goal achievement rates for glycemic control in Japanese patients with type 2 diabetes. Jpn Pharmacol Ther. 2012;41(10):965-974. Japanese [Abstract in English].

22. Kaku K. Efficacy and safety of anagliptin add-on therapy in Japanese patients with type 2 diabetes. Jpn Pharmacol Ther. 2012;40(9):745-770. Japanese [Abstract in English].

23. Mannucci E, Ognibene A, Cremasco F, et al. Effect of metformin on glucagon-like peptide 1 (GLP-1) and leptin levels in obese nondiabetic subjects. Diabetes Care. 2001;24(3):489-494.

24. Lindsay JR, Duffy NA, McKillop AM, et al. Inhibition of dipeptidyl peptidase IV activity by oral metformin in type 2 diabetes. Diabet Med. 2005;22(5):654-657.

25. Qualmann C, Nauck MA, Holst JJ, Orskov C, Creutzfeldt W. Glucagonlike peptide 1 (7-36 amide) secretion in response to luminal sucrose from the upper and lower gut. A study using alpha-glucosidase inhibition (acarbose). Scand J Gastroenterol. 1995;30(9):892-896.

26. Kim K, Kaku K. Drug interaction between anagliptin, a novel dipeptidyl peptidase- 4 inhibitor, and miglitol, an $\alpha$-glucosidase inhibitor, in Japanese patients with type 2 diabetes. Jpn Pharmacol Ther. 2012;40(10):871-881. Japanese [Abstract in English].

27. Kim K, Kaku K. Drug interaction between anagliptin, a novel $\alpha$-glucosidase inhibitor, and metformin in Japanese patients with type 2 diabetes. Jpn Pharmacol Ther. 2012;40(10):883-894. Japanese [Abstract in English].

28. Hermansen K, Kipnes M, Luo E, et al; Sitagliptin Study 035 Group. Efficacy and safety of the dipeptidyl peptidase-4 inhibitor, sitagliptin, in patients with type 2 diabetes mellitus inadequately controlled on glimepiride alone or on glimepiride and metformin. Diabetes Obes Metab. 2007;9(5):733-745.

29. Uchino H, Kaku K. A novel dipeptidyl peptidase-4 inhibitor, anagliptin, improved the daily blood glucose profile. Jpn Pharmacol Ther. 2012;40(10):859-869. Japanese [Abstract in English].

30. Sone H, Tanaka S, Tanaka S, et al; Japan Diabetes Complications Study Group. Serum level of triglycerides is a potent risk factor comparable to LDL cholesterol for coronary heart disease in Japanese patients with type 2 diabetes: subanalysis of the Japan Diabetes Complications Study (JDCS). J Clin Endocrinol Metab. 2011;96(11):3448-3456. 
31. Kaku K. Effects of anagliptin on serum lipids in Japanese patients with type 2 diabetes - a pooled analysis of long-term therapy with anagliptin. Jpn Pharmacol Ther. 2012;40(9):771-784. Japanese [Abstract in English].

32. Monami M, Ahrén B, Dicembrini I, Mannucci E. Dipeptidyl peptidase-4 inhibitors and cardiovascular risk: a meta-analysis of randomized clinical trials. Diabetes Obes Metab. 2013;15(2):112-120.

33. Ervinna N, Mita T, Yasunari E, et al. Anagliptin, a DPP-4 inhibitor, suppresses proliferation of vascular smooth muscles and monocyte inflammatory reaction and attenuates atherosclerosis in male apo E-deficient mice. Endocrinology. 2013;154(3):1260-1270.

34. Kakuda H, Kobayashi J, Kakuda M, Yamakawa J, Takekoshi N. The effect of anagliptin treatment on glucose metabolism and lipid metabolism, and oxidative stress in fasting and postprandial states using a test meal in Japanese men with type 2 diabetes. Endocrine. 2014.

35. Imai C, Harazaki T, Inoue S, Mochizuki K, Goda T. Inhibition of postprandial hyperglycemia by either an insulin-dependent or -independent drug reduces the expression of genes related to inflammation in peripheral leukocytes of OLETF rats. Biosci Biotechnol Biochem. 2013;77(11):2305-2308.

36. Mimura S, Ando T, Ishiguro K, et al. Dipeptidyl peptidase-4 inhibitor anagliptin facilitates restoration of dextran sulfate sodium-induced colitis. Scand J Gastroenterol. 2013;48(10):1152-1159.

37. Sanwa Kagaku Kenkyusho Co, Ltd 2015. Available from: http://med. skk-net.com/information/download/578/file1. Accessed January 25, 2015. [Japanese].
38. Hamasaki H, Yanai H. The development of angioedema in a patient with type 2 diabetes due to a novel dipeptidyl peptidase-IV inhibitor, anagliptin. Int J Cardiol. 2013;168(3):e106.

39. Brown NJ, Byiers S, Carr D, Maldonado M, Warner BA. Dipeptidyl peptidase-IV inhibitor use associated with increased risk of ACE inhibitor-associated angioedema. Hypertension. 2009;54(3):516-523.

40. Scirica BM, Bhatt DL, Braunwald E, et al; SAVOR-TIMI 53 Steering Committee and Investigators. Saxagliptin and cardiovascular outcomes in patients with type 2 diabetes mellitus. N Engl J Med. 2013;369(14): 1317-1326

41. Wu S, Hopper I, Skiba M, Krum H. Dipeptidyl peptidase-4 inhibitors and cardiovascular outcomes: meta-analysis of randomized clinical trials with 55,141 participants. Cardiovasc Ther. 2014;32(4):147-158.

42. White WB, Cannon CP, Heller SR, et al; EXAMINE Investigators. Alogliptin after acute coronary syndrome in patients with type 2 diabetes. N Engl J Med. 2013;369(14):1327-1335.

43. White WB, Pratley R, Fleck P, et al. Cardiovascular safety of the dipeptidyl peptidase-4 inhibitor alogliptin in type 2 diabetes mellitus. Diabetes Obes Metab. 2013;15(7):668-673.

44. Ito $\mathrm{H}, \mathrm{Abe} \mathrm{M}, \mathrm{Antoku} \mathrm{S}$, et al. Comparison of the antidiabetic effects of linagliptin among groups with a normal renal function and a mild or severe renal impairment - retrospective observation study of Japanese patients with type 2 diabetes mellitus. Expert Opin Pharmacother. 2015;16(3):289-296.

45. Ando S, Tsugami E, Suzuki S, et al. Recent trend in the prescription rates of antidiabetic agents in our facility. Journal of Japan Diabetes Society. 2013; 56 Suppl 1: S164.

\section{Publish your work in this journal}

Diabetes, Metabolic Syndrome and Obesity: Targets and Therapy is an international, peer-reviewed open-access journal committed to the rapid publication of the latest laboratory and clinical findings in the fields of diabetes, metabolic syndrome and obesity research. Original research, review, case reports, hypothesis formation, expert opinion and commentaries are all considered for publication. The manuscript management system is completely online and includes a very quick and fair peer-review system, which is all easy to use. Visit http://www.dovepress.com/testimonials.php to read real quotes from published authors. 